\title{
Peningkatan Kreativitas Mahasiswa melalui Model Pembelajaran Brainstorming pada Mata Kuliah Pengantar Geografi di Universitas Pasir Pengaraian
}

\author{
Ike Betria, Romika Rahayu \\ Dosen Program Studi Pendidikan IPS Universitas Pasir Pengaraian \\ Email: ikebetria1986@gmail.com,
}

\begin{abstract}
ABSTRAK
Berdasarkan hasil observasi pada kelas pengantar geografi di Prodi Pendidikan IPS Universitas Pasir Pengaraian menunjukkan rendahnya kreativitas mahasiswa, sehingga penelitian ini bertujuan untuk mendapatkan informasi dan mengemukakan peningkatan kreativitas mahasiswa melalui model pembelajaran Brainstorming pada mata kuliah pengantar geografi di Prodi Pendidikan IPS Universitas Pasir Pengaraian. Jenis penelitian yang digunakan oleh peneliti adalah Penelitian Tindakan Kelas (PTK) dengan pendekatan kualitatif yang dilaksanakan pada bulan Mei tahun ajaran 2018/2019. Penelitian dilakukan sebanyak dua siklus, siklus I dan II dilaksanakan sebanyak dua kali pertemuan dengan prosedur penelitian terdiri dari perencanaan, pelaksanaan, observasi dan refleksi. Subjek penelitian adalah mahasiswa pengantar geografi Prodi Pendidikan IPS Universitas Pasir Pengaraian yang berjumlah 27 mahasiswa. Instrumen pengumpulan data yang digunakan berbentuk lembar observasi, angket, wawancara dan catatan lapangan. Data dianalisis secara deskriptif dan persentase. Hasil penelitian menunjukkan jumlah rata-rata kreativitas mahasiwa juga mengalami peningkatan dengan persentase rata-rata pada siklus I pertemuan pertama adalah $57,41 \%$, pada pertemuan kedua rata-ratanya $75 \%$ dan mengalami peningkatan yang signifikan pada siklus II pertemuan pertama dengan rata-rata $80,25 \%$ meningkat pada pertemuan kedua dengan persentase rata-rata $89,81 \%$. Dengan demikian penerapan model Brainstroming dapat meningkatkan dan kreativitas mahasiswa pada mata kuliah pengantar geografi Prodi Pendidikan IPS Universitas Pasir Pengaraian.
\end{abstract}

Kata Kunci : Kreativitas, Mahasiswa, Pengantar Geografi

\section{PENDAHULUAN}

Mata Kuliah Pengantar Geografi merupakan mata kuliah wajib bagi mahasiswa Program Studi Pendidikan Ilmu Pengetahuan Sosial. Tujuan Mata Kuliah Pengantar Geografi untuk mengembangkan perilaku mahasiswa yang mencakup aspek kognitif, afektif dan psikomotor, sehingga melalui Mata Kuliah Pengantar Geografi diharapkan mahasiswa dapat mengalami perkembangan baik dari perilaku maupun keterampilannya. Pada hakikatnya Mata Kuliah Pengantar Geografi adalah mata kuliah wajib diikuti oleh para mahasiswa Universitas Pasir Pengaraian di samping mata kuliah lainnya. Mata kuliah ini mengutamakan pengetahuan dan pemahaman awal tentang geografi serta kedudukannya di tengah ilmu pengetahuan lainnya, yang pada akhirnya dapat dimanfaatkan untuk menjawab berbagai permasalahan yang terjadi di tengah masyarakat melalui sudut pandang geografi.
Harapan ini hanya bisa terwujud dengan bantuan dan bimbingan dari para pendidik, khususnya dosen geografi.

B. F. Skinner adalah seorang yang berkebangsaan Amerika yang dikenal sebagai seorang tokoh behavioris yang meyakini bahwa perilaku individu dikontrol melalui proses operant conditioning dimana seseorang dapat mengontrol tingkah laku organisme melalui pemberian reinforcement yang bijaksana dalam lingkungan yang relatif besar. Menagement kelas menurut skinner adalah berupa usaha untuk memodifikasi perilaku antara lain dengan proses penguatan yaitu memberi penghargaan pada perilaku yang diinginkan dan tidak memberi imbalan apapun pada perilaku yang tidak tepat.

Dalam penyelenggaraan akademik di Universitas Pasir Pengaraian sejak awal berdiri telah dilakukan berbagai upaya untuk meningkatkan kualitas proses pendidikan. 
Upaya-upaya seperti peningkatan kualitas staf pengajar (dosen) melalui jenjang pendidikan formal dari S-1 ke S-2/S-3 dan peningkatan kualitas dosen melalui non-degree training (magang). Selain itu peningkatan sarana penunjang kegiatan akademik di Universitas Pasir Pengaraian, laboratorium, perpustakaan, peninjauan kurikulum, dan perbaikan kualitas materi perkuliahan terus dilakukan untuk meningkatkan kualitas akademik.

Namun pada kenyataannya, UPP masih memiliki beberapa permasalahan salah satunya dalam proses perkuliahan, di mana dosen masih sering menggunakan model pembelajaran konvensional, yaitu ceramah maupun diskusi satu arah, sehingga tidak banyak melibatkan mahasiswa selama proses perkuliahan. Salah satunya, yang terjadi pada Prodi IPS pada Mata Kuliah Pengantar Geografi. Selama ini dosen hanya menggunakan metode ceramah satu arah ataupun memberi tugas pada mahasiswa, sehingga pada akhirnya mahasiswa menjadi malas, dan tidak dapat mengembangkan kemampuan kreativitasnya selama proses perkuliahan, hal ini terlihat ketika peneliti melakukan observasi awal, di mana mahasiswa dalam proses pembelajaran cenderung diam dan tidak memberikan respon yang positif, seperti hanya satu atau dua mahasiswa yang memberikan tanggapan maupun berperan aktif selama proses perkuliahan.

Pengembangan kreativitas dalam perkuliahan merupakan suatu upaya yang sangat penting dilakukan. Hal ini sesuai dengan salah satu tujuan dari pendidikan tinggi, yaitu mentransformasikan dan mengembangkan kemampuan mahasiswa, termasuk untuk merancang apa yang akan dilakukan, melaksanakan apa yang sudah direncanakan, memonitor dan mengevaluasi apa yang sedang dan sudah dilakukan, sehingga mereka menjadi kritis, kreatif, inovatif, mandiri, percaya diri, dan bertanggung jawab (Peraturan Pemerintah nomor 17 tahun 2010 tentang pengelolaan dan penyelenggaraan pendidikan). Kreativitas mempunyai definisi yang beragam tergantung bagaimana penekanannya. Namun pada intinya ada persamaan antara definisi-definisi tersebut yaitu, kreativitas merupakan kemampuan seseorang untuk melahirkan sesuatu yang baru, baik berupa gagasan maupun karya nyata, yang relatif berbeda dengan apa yang ada sebelumnya (Supriadi, 1994: 7).

Hal ini menunjukkan bahwa kreativitas mahasiswa sangat penting, salah satu cara untuk meningkatkannya adalah dengan menggunakan model pembelajaran yang mampu mengasah kemampuan tersebut. Model pembelajaran Brainstorming merupakan suatu metode pembelajaran yang mengajak mahasiswa untuk aktif mengeluarkan gagasan. Mahasiswa merasa lebih dihargai dan termotivasi jika pendapat mereka tidak langsung ditolak atau dianggap salah. Metode pembelajaran ini memberikan kebebasan kepada mahasiswa untuk menyalurkan ide tanpa ada kritikan, semua gagasan dari mahasiswa ditampung dalam bentuk tulisan. Kebebasan berpendapat mengajarkan kepada mahasiswa bagaimana berpikir secara divergen. Salah satu cara untuk meningkatkan kreativitas melalui pelatihan, dan berpendapat merupakan salah satu cara pelatihan yang dirancang oleh dosen /dosen supaya mahasiswa mau mengeluarkan gagasan (Sotte, Lentz \& Mumford : 2001).

\section{METODE PENELITIAN}

Penelitian ini merupakan jenis penelitian tindakan Tindakan kelas atau ClassroomAction Research. Menurut Arikunto (2010:130) bahwa penelitian tindakan kelas merupakan paparan gabungan definisi dari tiga kata "penelitian, tindakan dan kelas". Penelitian merupakan kegiatan mencermati suatu objek, menggunakan aturan metodologi tertentu untuk memperoleh data atau informasi yang bermanfaat bagi peneliti atau orang-orang yang berkepentingan dalam rangka peningkatan kualitas di berbagai bidang. Tindakan adalah suatu gerak kegiatan yang sengaja dilakukan dengan tujuan tertentu yang dalam pelaksanaannya berbentuk rangkaian periode/siklus kegiatan. Sedangkan kelas merupakan sekelompok mahasiswa yang dalam waktu yang sama dan tempat yang sama menerima pelajaran yang sama dari dosen yang sama. 
Penelitian tindakan kelas yang digunakan dalam penelitian ini adalah penelitian partisipan, yaitu peneliti terlibat secara penuh dan langsung dalam proses penelitian mulai dari awal sampai akhir penelitian. Dalam hal ini peneliti melakukan kolaborasi dengan teman sejawat dengan dosen lain, dan mahasiswa untuk membantu mencari solusi yang efektif dalam pembelajaran dengan menggunakan model pembelajaran Brainstorming untuk meningkatkan kreativitas mahasiswa pada Mata Kuliah Pengantar Geografi di Prodi Pendidikan IPS Universitas Pasir Pengaraian

Penelitian berlangsung di Prodi Pendidikan IPS Universitas Pasir Pengaraian yang berlokasi di Jl. Tuanku Tambusai, Rambah, Pasir Pengaraian, Kabupaten Rokan Hulu, Riau. Dalam penelitian ini adapun subjek yang akan diteliti dalam penelitian ini adalah mahasiswa yang mengambil Mata Kuliah Pengantar Geografi Universitas Pasir Pengaraian yang berjumlah 27 mahasiswa. Penelitian ini dilaksanakan di Universitas Pasir Pengaraian, dan dilaksanakan selama delapan minggu. Dimulai pada bulan April - Mei tahun ajaran 2018/2019 pelaksanaan pertama pada bulan Mei 2019.

Rencana tindakan merupakan gambaran tentang langkah-langkah rill yang akan dilakukan dalam tindakan. Ada empat tahap yang akan dilalui dalam penelitian tindakan yaitu perencanaan, pelaksanaan, pengamatan, dan refleksi. Keempat langkah ini terus dilakukan berulang sampai perbaikan yang diharapkan dapat tercapai. Rancangan penelitian yang dilakukan dapat dilihat pada gambar

berikut:

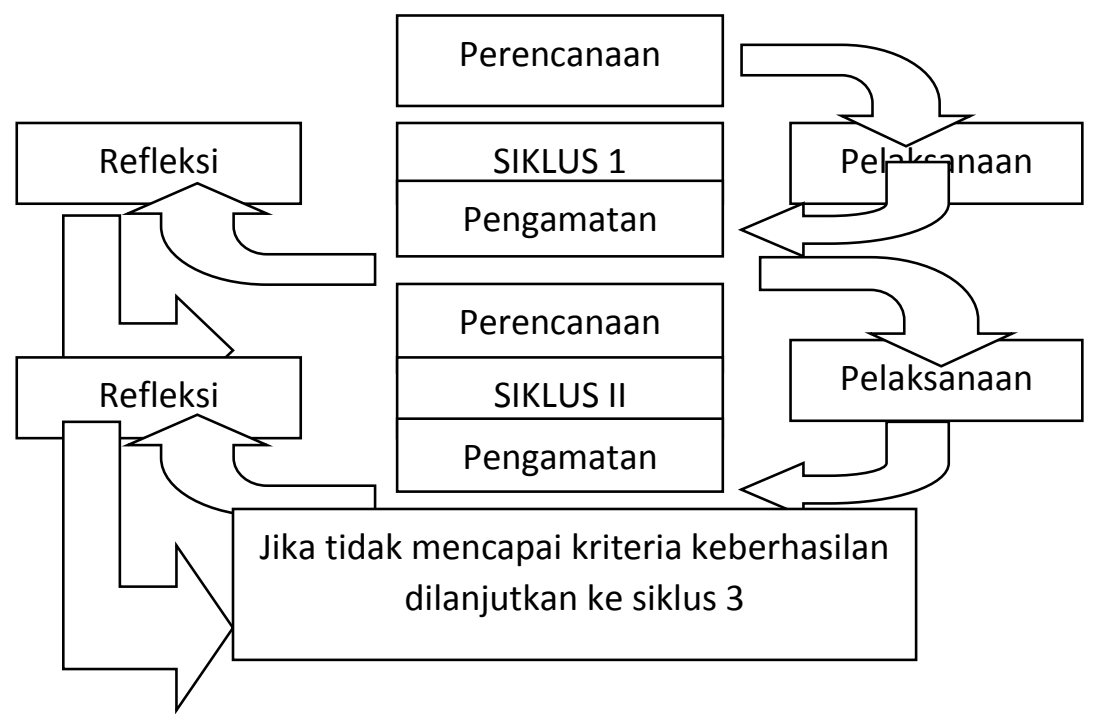

Gambar 1. Model Penelitian Tindakan Kelas

Sumber: Susilo (2010: 19)

Instrumen penelitian yang digunakan dalam penelitian lembar observasi, wawancara, catatan lapangan, dokumentasi. Lembar observasi ini digunakan untuk mengamati kreativitas mahasiswa pada setiap pertemuannya. Lembar observasi yang digunakan disusun berdasarkan model pembelajaran Brainstroming. Adapun butir-butir lembar observasi tertera dalam tabel kisi-kisi tabel dibawah ini :

Tabel . Kisi-kisi lembar observai keativitas Mahasiswa

\begin{tabular}{|c|l|l|c|}
\hline \multicolumn{2}{|c|}{ Aspek Kreativitas } & \multicolumn{1}{c|}{ Indikator } & $\begin{array}{c}\text { Nomor } \\
\text { Item }\end{array}$ \\
\hline Aptitude & $\begin{array}{l}\text { 1. Keterampilan Berpikir } \\
\text { Lancar }\end{array}$ & $\begin{array}{l}\text { Mencetuskan banyak gagasan, } \\
\text { jawaban, saran dalam penyelesaian }\end{array}$ & 1 \\
\hline
\end{tabular}




\begin{tabular}{|c|c|c|c|}
\hline & & masalah & \\
\hline & & $\begin{array}{l}\text { Bekerja lebih cepat dan melakukan } \\
\text { lebih banyak dari yang lain }\end{array}$ & 2 \\
\hline & & Menghasilkan gagasan yang bervariasi & 3 \\
\hline & 2. Keterampilan berpikir & $\begin{array}{l}\text { Dapat melihat masalah dari berbagai } \\
\text { sudut pandang yang berbeda }\end{array}$ & 4 \\
\hline & luwes & $\begin{array}{l}\text { Dapat menerapkan konsep, sifat, atau } \\
\text { aturan dalam contoh pemecahan } \\
\text { masalah }\end{array}$ & 5 \\
\hline & 3. Keterampilan berpikir & $\begin{array}{l}\text { Mencetuskan masalah, gagasan atau } \\
\text { hal-hal yang tidak terpikirkan orang } \\
\text { lain }\end{array}$ & 6 \\
\hline & & $\begin{array}{l}\text { Menciptakan ide-ide atau hasil karya } \\
\text { yang berbeda dan betul-betul baru }\end{array}$ & 7 \\
\hline & 4. Keterampilan berpikir & $\begin{array}{l}\text { Mengembangkan atau memperkaya } \\
\text { gagasan orang lain }\end{array}$ & 8 \\
\hline & detail (elaborasi) & $\begin{array}{l}\text { Membuat laporan dengan detail dan } \\
\text { berbeda }\end{array}$ & 9 \\
\hline & 5. Rasa ingin tahu & $\begin{array}{l}\text { Keinginan untuk mencari tahu, } \\
\text { mendalami pengetahuan lebih dalam }\end{array}$ & 10 \\
\hline $\begin{array}{l}\text { Non- } \\
\text { Antitude }\end{array}$ & & Mempertanyakan segala sesuatu & 11 \\
\hline Артитае & $\begin{array}{l}\text { 6. Bersikap merasa } \\
\text { tertantang }\end{array}$ & $\begin{array}{l}\text { Melibatkan diri dalam tugas yang } \\
\text { diberikan }\end{array}$ & 12 \\
\hline
\end{tabular}

Dalam penelitian ini data dianalisis dengan metode yang di kemukakan oleh Miller dan Heberman yang dikutip oleh Sugiyono (2005) yaitu dengan langkah-langkah sebagai berikut:

a. Reduksi Data

Reduksi data adalah proses pemilihan, pemusatan, perhatian pada penyederhanaan, pengabsahan dan transformasi data kasar yang muncul dari cacatan-cacatan tertulis di lapangan. reduksi data terus berlangsung selama penelitian, jadi reduksi data adalah bentuk analisis yang menggolongkan, membuang data yang tidak dibutuhkan dan mengorganisasikannya sehingga kesimpulan akhir dapat ditarik.

\section{b. Penyajian Data}

Penyajian data merupakan sekumpulan informasi yang tersusun yang memberikan kemungkinan adanya penarikan kesimpulan dan pengambilan tindakan, dalam penyajian data ini peneliti melakukan pengelompokan, penyusunan data berdasarkan kategori dan urutannya sehingga strukturnya dapat dipahami dan memberikan kemungkinan adanya penarikan kesimpulan.

c. Pengambilan Keputusan
Dalam penelitian ini, peneliti berusaha untuk memperoleh informasi tentang variabel yang diteliti. Jadi data yang diperoleh dari lapangan ditarik kesimpulannya dan akhirnya akan menjadi hasil penelitian. Data kreativitas mahasiswa dianalisis dengan mencari skor ratarata dengan menggunakan rumus:

Skor

$=\frac{\text { skor hasil observasi kreativitas }}{\text { skor maksimal }} \times 100 \%$

Kriteria keberhasilan merupakan sebuah patokan yang harus dicapai di dalam sebuah penelitian. Pada penelitian ini kriteria keberhasilan ditentukan apabila tingkat kreativitas dan kemampuan metakognisi mahasiswa meningkat yang dapat diketahui dari lembar observasi dan angket yang telah ada. Menurut Ngalim (2002: 103) kriteria keberhasilan dapat dilihat dari pedoman penilaian sebagai berikut:

$$
\begin{aligned}
& >54 \%=\text { kurang sekali } \\
& 55-59 \%=\text { kurang } \\
& 60-75 \%=\text { cukup }
\end{aligned}
$$


$76-85 \%$ = baik

$85-100 \%=$ sangat baik

Sehingga dapat dikatakan berhasil apabila terjadi peningkatan kreativitas mahasiswa setelah diterapkannya pembelajaran Brainstroming sebesar $76 \%$ dari rata-rata indikator kreativitas mahasiswa pada Mata Kuliah Pengantar Geografi.

\section{HASIL DAN PEMBAHASAN}

Berdasarkan hasil observasi penelitian pada siklus I pertemuan pertama diperoleh data hasil kreativitas belajar mahasiswa selama proses perkuliahan dengan menggunakan model pembelajaran Brainstroming pada Mata Kuliah Pengantar Geografi. Berikut ini adalah hasil pengamatan kreativitas belajar mahasiswa yang disajikan pada tabel berikut ini:

Tabel 2. Hasil Pengamatan Kreativitas Mahasiswa pada Siklus I Pertemuan 1

\begin{tabular}{|c|c|c|c|c|}
\hline \multirow{2}{*}{$\begin{array}{c}\text { Aspek } \\
\text { Kreativitas }\end{array}$} & \multirow[b]{2}{*}{ Indikator } & \multicolumn{3}{|c|}{ Kreativitas Belajar Mahasiswa } \\
\hline & & Frekuensi & $\begin{array}{l}\text { Persentas } \\
\text { e }(\%)\end{array}$ & Kategori \\
\hline \multirow{2}{*}{$\begin{array}{l}\text { Keterampilan } \\
\text { Berpikir Lancar }\end{array}$} & $\begin{array}{l}\text { 1) Mencetuskan banyak gagasan, } \\
\text { jawaban, saran dalam } \\
\text { penyelesaian masalah }\end{array}$ & 19 & 70,37 & Cukup \\
\hline & $\begin{array}{l}\text { 2) Bekerja lebih cepat dan } \\
\text { melakukan lebih banyak dari } \\
\text { yang lain }\end{array}$ & 13 & 48,15 & $\begin{array}{l}\text { Kurang } \\
\text { Sekali }\end{array}$ \\
\hline \multirow{3}{*}{$\begin{array}{l}\text { Keterampilan } \\
\text { berpikir luwes }\end{array}$} & $\begin{array}{l}\text { 3) Menghasilkan gagasan yang } \\
\text { bervariasi }\end{array}$ & 15 & 55,56 & Kurang \\
\hline & $\begin{array}{l}\text { 4) } \begin{array}{l}\text { Dapat melihat masalah dari } \\
\text { berbagai sudut pandang yang } \\
\text { berbeda }\end{array} \\
\end{array}$ & 15 & 55,56 & Kurang \\
\hline & $\begin{array}{l}\text { 5) Dapat menerapkan konsep, sifat, } \\
\text { atau aturan dalam contoh } \\
\text { pemecahan masalah }\end{array}$ & 18 & 59,24 & Kurang \\
\hline \multirow{2}{*}{$\begin{array}{l}\text { Keterampilan } \\
\text { berpikir orisinil }\end{array}$} & $\begin{array}{l}\text { 6) Mencetuskan masalah, gagasan } \\
\text { atau hal-hal yang tidak } \\
\text { terpikirkan orang lain }\end{array}$ & 12 & 44,44 & $\begin{array}{l}\text { Kurang } \\
\text { Sekali }\end{array}$ \\
\hline & $\begin{array}{l}\text { 7) } \begin{array}{l}\text { Menciptakan ide-ide atau hasil } \\
\text { karya yang berbeda dan betul- } \\
\text { betul baru }\end{array} \\
\end{array}$ & 18 & 66,67 & Cukup \\
\hline \multirow{2}{*}{$\begin{array}{l}\text { Keterampilan } \\
\text { berpikir detail } \\
\text { (elaborasi) }\end{array}$} & $\begin{array}{l}\text { 8) Mengembangkan atau } \\
\text { memperkaya gagasan orang lain }\end{array}$ & 14 & 51,85 & $\begin{array}{l}\text { Kurang } \\
\text { Sekali }\end{array}$ \\
\hline & $\begin{array}{l}\text { 9) Membuat laporan dengan detail } \\
\text { dan berbeda }\end{array}$ & 13 & 48,15 & $\begin{array}{l}\text { Kurang } \\
\text { Sekali }\end{array}$ \\
\hline \multirow[t]{2}{*}{ Rasa ingin tahu } & $\begin{array}{l}\text { 10) Keinginan untuk mencari tahu, } \\
\text { mendalami pengetahuan lebih } \\
\text { dalam }\end{array}$ & 18 & 66,67 & Cukup \\
\hline & 11) Mempertanyakan segala sesuatu & 18 & 66,67 & Cukup \\
\hline $\begin{array}{l}\text { Bersikap merasa } \\
\text { tertantang }\end{array}$ & $\begin{array}{l}\text { 12) Melibatkan diri dalam tugas } \\
\text { yang diberikan }\end{array}$ & 15 & 55,56 & Kurang \\
\hline
\end{tabular}

Sumber : Pengolahan Pribad 
Berikut ini adalah hasil pengamatan kreativitas belajar mahasiswa pada pertemuan ke-2 di Siklus I yang disajikan pada tabel berikut ini:

Tabel 3. Hasil Pengamatan Kreativitas Mahasiswa pada Siklus I Pertemuan 2

\begin{tabular}{|c|c|c|c|c|}
\hline \multirow{2}{*}{$\begin{array}{c}\text { Aspek } \\
\text { Kreativitas }\end{array}$} & \multirow[b]{2}{*}{ Indikator } & \multicolumn{3}{|c|}{ Kreativitas Belajar Mahasiswa } \\
\hline & & Frekuensi & $\begin{array}{l}\text { Persentas } \\
\text { e }(\%)\end{array}$ & Kategori \\
\hline \multirow{2}{*}{$\begin{array}{l}\text { Keterampilan } \\
\text { Berpikir } \\
\text { Lancar }\end{array}$} & $\begin{array}{l}\text { 1) Mencetuskan banyak } \\
\text { gagasan, jawaban, saran } \\
\text { dalam penyelesaian } \\
\text { masalah }\end{array}$ & 23 & 85,19 & Baik \\
\hline & $\begin{array}{l}\text { 2) Bekerja lebih cepat dan } \\
\text { melakukan lebih banyak } \\
\text { dari yang lain }\end{array}$ & 17 & 62,96 & Cukup \\
\hline \multirow{3}{*}{$\begin{array}{l}\text { Keterampilan } \\
\text { berpikir luwes }\end{array}$} & $\begin{array}{l}\text { 3) Menghasilkan gagasan yang } \\
\text { bervariasi }\end{array}$ & 19 & 70,37 & Cukup \\
\hline & $\begin{array}{l}\text { 4) Dapat melihat masalah dari } \\
\text { berbagai sudut pandang } \\
\text { yang berbeda }\end{array}$ & 20 & 74,07 & Cukup \\
\hline & $\begin{array}{l}\text { 5) Dapat menerapkan konsep, } \\
\text { sifat, atau aturan dalam } \\
\text { contoh pemecahan masalah }\end{array}$ & 22 & 81,48 & Baik \\
\hline \multirow{2}{*}{$\begin{array}{l}\text { Keterampilan } \\
\text { berpikir } \\
\text { orisinil }\end{array}$} & $\begin{array}{l}\text { 6) Mencetuskan masalah, } \\
\text { gagasan atau hal-hal yang } \\
\text { tidak terpikirkan orang lain }\end{array}$ & 16 & 59,26 & Kurang \\
\hline & $\begin{array}{l}\text { 7) Menciptakan ide-ide atau } \\
\text { hasil karya yang berbeda } \\
\text { dan betul-betul baru }\end{array}$ & 21 & 77,78 & Baik \\
\hline \multirow{2}{*}{$\begin{array}{l}\text { Keterampilan } \\
\text { berpikir detail } \\
\text { (elaborasi) }\end{array}$} & $\begin{array}{l}\text { 8) Mengembangkan atau } \\
\text { memperkaya gagasan orang } \\
\text { lain }\end{array}$ & 17 & 62,96 & Cukup \\
\hline & $\begin{array}{l}\text { 9) Membuat laporan dengan } \\
\text { detail dan berbeda }\end{array}$ & 18 & 66,67 & Cukup \\
\hline \multirow{2}{*}{$\begin{array}{l}\text { Rasa ingin } \\
\text { tahu }\end{array}$} & $\begin{array}{l}\text { 10) Keinginan untuk mencari } \\
\text { tahu, mendalami } \\
\text { pengetahuan lebih dalam }\end{array}$ & 24 & 88,89 & $\begin{array}{l}\text { Sangat } \\
\text { Baik }\end{array}$ \\
\hline & $\begin{array}{l}\text { 11) Mempertanyakan segala } \\
\text { sesuatu }\end{array}$ & 21 & 77,78 & Baik \\
\hline $\begin{array}{l}\text { Bersikap } \\
\text { merasa } \\
\text { tertantang }\end{array}$ & $\begin{array}{l}\text { 12) Melibatkan diri dalam tugas } \\
\text { yang diberikan }\end{array}$ & 25 & 92,59 & $\begin{array}{l}\text { Sangat } \\
\text { Baik }\end{array}$ \\
\hline
\end{tabular}

Sumber : Pengolahan Pribadi

Peningkatan kreativitas belajar mahasiswa pada siklus I dapat dilihat pada diagram batang di bawah ini: 


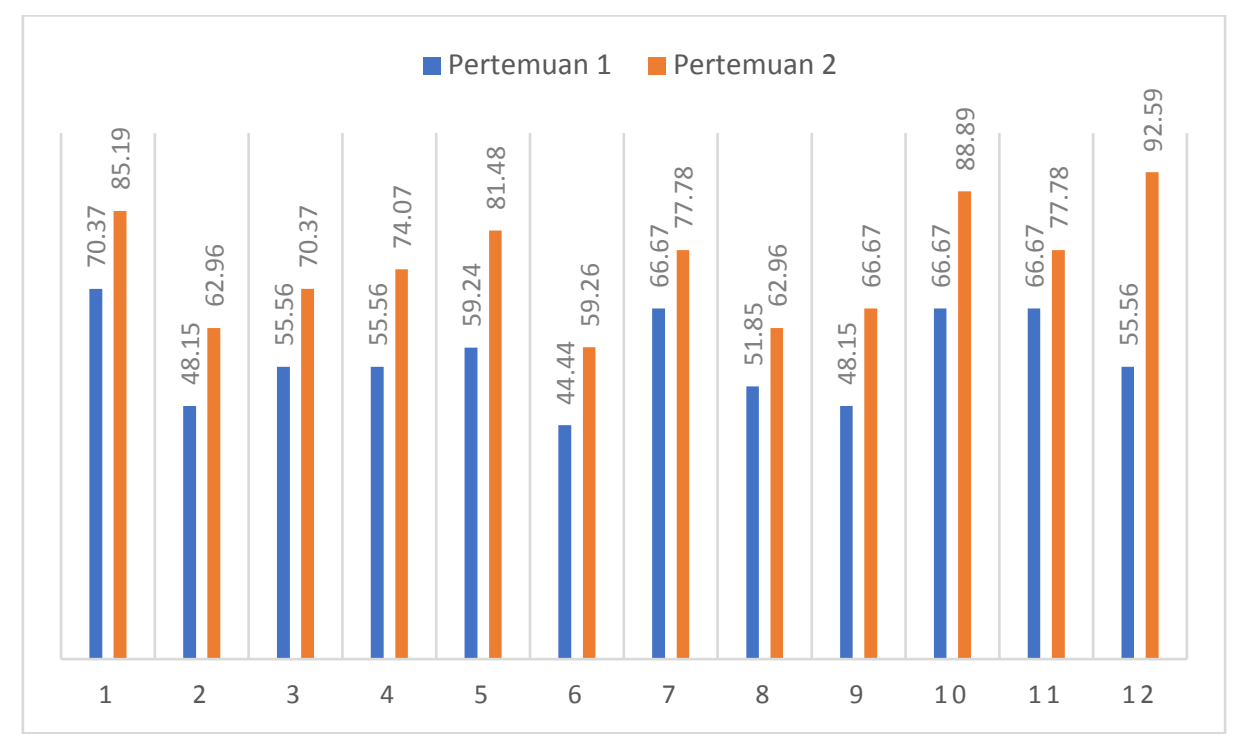

Gambar 2. Diagram Peningkatan Kreativitas Belajar Mahasiswa Siklus I

\section{Tahap Refleksi}

Berdasarkan hasil penelitian di siklus I, dapat diketahui bahwa kreativitas mahasiswa menunjukkan hasil 64,20\% dengan kategori cukup. Hasil ini belum sesuai dengan kriteria keberhasilan penelitian sehingga masih perlu ditingkatkan karena kedua variabel penelitian masih termasuk dalam kategori cukup. Dan ditambah dari hasil wawancara yang dilakukan dengan observer terkait kelemahan-kelemahan selama proses pembelajaran salah satunya, beliau memaparkan,

"menurut ibu selaku observer, model yang digunakan sangat menarik namun ike masih terlalu terpaku dengan SAP yang telah dibuat sehingga perkuliah nampak kaku dan mahasiswa menjadi tergesa-gesa dan kemudain merasa bosan, jadi ada baiknya pada pertemuan selanjutnya ike lebih fleksibel sehingga mahasiswa akan lebih aktif dalam proses perkuliahan"

Dari hasil refleksi yang diperoleh dapat diuraikan sebagai berikut:

1) Selama proses perkuliahan berlangsung, peneliti telah melaksanakan tahapan pembelajaran, namun hal ini membuat proses perkuliahan menjadi kaku dan peneliti kurang bisa mengefektifkan waktu.

2) Peneliti tidak menyampaikan model pembelajaran yang digunakan serta tahapan pembelajaran sehingga ada mahasiswa yang bingung dengan proses perkuliahan.

3) Berdasarkan hasil pengamatan diketahui bahwa mahasiswa kurang konsentrasi, sehingga banyak mahasiswa yang tidak aktif selama proses perkuliahan dan berdampak pada rendahnya tingkat kemampuan metakognisi dan kreativitas mahasiswa

Berdasarkan hasil refleksi di atas upaya yang perlu dilakukan peneliti untuk meningkatkan kemampuan metakognisi dan kreativitas mahasiswa yaitu peneliti harus lebih fleksibel selama proses pembelajaran tidak terlalu terpaku kepada SAP yang telah dibuat, namun menyesuaikan tahapan model pembelajaran dengan situasi dan kondisi di kelas, menyampaikan model pembelajaran yang digunakan serta tahapan-tahapan yang ada serta memberikan pujian kepada mahasiswa yang aktif dan kreatif dalam mempresentasikan hasil diskusinya dan menyampaikan pendapat agar mahasiswa lebih berkonsentrasi dan lebih aktif selama proses perkuliahan berlangsung. Berdasarkan hal ini akan dilakukan penelitian pada siklus berikutnya yaitu siklus II.

Berikut adalah hasil dari pengamatan atau observasi dari observer terkait kreativitas mahasiswa selama proses perkuliahan di siklus II dengan menggunakan model pembelajaran Brainstroming pada Mata Kuliah Pengantar Geografi; 
Tabel 4. Hasil Pengamatan Kreativitas Mahasiswa pada Siklus II Pertemuan 1

\begin{tabular}{|c|c|c|c|c|}
\hline \multirow{2}{*}{$\begin{array}{c}\text { Aspek } \\
\text { Kreativitas }\end{array}$} & \multirow[b]{2}{*}{ Indikator } & \multicolumn{3}{|c|}{ Kreativitas Belajar Mahasiswa } \\
\hline & & Frekuensi & $\begin{array}{c}\text { Persentas } \\
\text { e }(\%)\end{array}$ & Kategori \\
\hline \multirow{2}{*}{$\begin{array}{l}\text { Keterampilan } \\
\text { Berpikir Lancar }\end{array}$} & $\begin{array}{l}\text { 1) Mencetuskan banyak } \\
\text { gagasan, jawaban, saran } \\
\text { dalam penyelesaian } \\
\text { masalah }\end{array}$ & 24 & 88,89 & $\begin{array}{l}\text { Sangat } \\
\text { Baik }\end{array}$ \\
\hline & 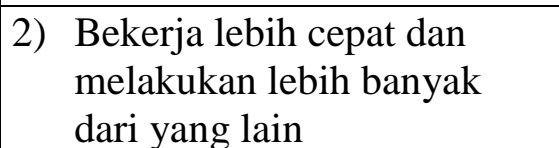 & 20 & 74,07 & Cukup \\
\hline \multirow{3}{*}{$\begin{array}{l}\text { Keterampilan } \\
\text { berpikir luwes }\end{array}$} & $\begin{array}{l}\text { 3) Menghasilkan gagasan yang } \\
\text { bervariasi }\end{array}$ & 20 & 74,07 & Cukup \\
\hline & $\begin{array}{l}\text { 4) } \begin{array}{l}\text { Dapat melihat masalah dari } \\
\text { berbagai sudut pandang } \\
\text { yang berbeda }\end{array} \\
\end{array}$ & 21 & 77,78 & Baik \\
\hline & $\begin{array}{l}\text { 5) Dapat menerapkan konsep, } \\
\text { sifat, atau aturan dalam } \\
\text { contoh pemecahan masalah }\end{array}$ & 23 & 85,19 & $\begin{array}{l}\text { Sangat } \\
\text { Baik }\end{array}$ \\
\hline \multirow{2}{*}{$\begin{array}{l}\text { Keterampilan } \\
\text { berpikir orisinil }\end{array}$} & 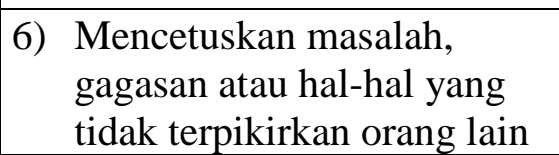 & 18 & 66,67 & Cukup \\
\hline & $\begin{array}{l}\text { 7) Menciptakan ide-ide atau } \\
\text { hasil karya yang berbeda } \\
\text { dan betul-betul baru }\end{array}$ & 23 & 85,19 & $\begin{array}{l}\text { Sangat } \\
\text { Baik }\end{array}$ \\
\hline \multirow{2}{*}{$\begin{array}{l}\text { Keterampilan } \\
\text { berpikir detail } \\
\text { (elaborasi) }\end{array}$} & $\begin{array}{l}\text { 8) Mengembangkan atau } \\
\text { memperkaya gagasan orang } \\
\text { lain }\end{array}$ & 20 & 74,07 & Cukup \\
\hline & $\begin{array}{l}\text { 9) Membuat laporan dengan } \\
\text { detail dan berbeda }\end{array}$ & 19 & 70,37 & Cukup \\
\hline \multirow[t]{2}{*}{ Rasa ingin tahu } & $\begin{array}{l}\text { 10) Keinginan untuk mencari } \\
\text { tahu, mendalami } \\
\text { pengetahuan lebih dalam }\end{array}$ & 24 & 88,89 & $\begin{array}{c}\text { Sangat } \\
\text { Baik }\end{array}$ \\
\hline & $\begin{array}{l}\text { 11) Mempertanyakan segala } \\
\text { sesuatu }\end{array}$ & 22 & 81,48 & Baik \\
\hline $\begin{array}{l}\text { Bersikap merasa } \\
\text { tertantang }\end{array}$ & $\begin{array}{l}\text { 12) Melibatkan diri dalam tugas } \\
\text { yang diberikan }\end{array}$ & 26 & 96,30 & $\begin{array}{c}\text { Sangat } \\
\text { Baik }\end{array}$ \\
\hline
\end{tabular}

Sumber : Pengolahan Pribadi

Berikut ini adalah hasil pengamatan kreativitas belajar mahasiswa pada pertemuan ke-2 di Siklus II yang disajikan pada tabel berikut ini:

Tabel 5. Hasil Pengamatan Kreativitas Mahasiswa pada Siklus II Pertemuan 2

\begin{tabular}{|l|c|c|c|c|}
\hline \multirow{2}{*}{$\begin{array}{c}\text { Aspek } \\
\text { Kreativitas }\end{array}$} & \multicolumn{1}{|c|}{ Indikator } & \multicolumn{3}{c|}{ Kreativitas Belajar Mahasiswa } \\
\cline { 3 - 5 } & Frekuensi & $\begin{array}{c}\text { Persentas } \\
\text { e (\%) }\end{array}$ & Kategori \\
\hline $\begin{array}{l}\text { Keterampila } \\
\text { n Berpikir }\end{array}$ & $\begin{array}{r}\text { 1) } \\
\text { Mencetuskan banyak gagasan, } \\
\text { jawaban, saran dalam }\end{array}$ & 26 & 96,30 & $\begin{array}{c}\text { Sangat } \\
\text { Baik }\end{array}$ \\
\hline
\end{tabular}




\begin{tabular}{|c|c|c|c|c|}
\hline \multirow{2}{*}{$\begin{array}{c}\text { Aspek } \\
\text { Kreativitas }\end{array}$} & \multirow{2}{*}{ Indikator } & \multicolumn{3}{|c|}{ Kreativitas Belajar Mahasiswa } \\
\hline & & Frekuensi & $\begin{array}{l}\text { Persentas } \\
\text { e }(\%)\end{array}$ & Kategori \\
\hline \multirow[t]{2}{*}{ Lancar } & penyelesaian masalah & & & \\
\hline & $\begin{array}{l}\text { 2) Bekerja lebih cepat dan } \\
\text { melakukan lebih banyak dari } \\
\text { yang lain }\end{array}$ & 24 & 88,89 & $\begin{array}{l}\text { Sangat } \\
\text { Baik }\end{array}$ \\
\hline \multirow{3}{*}{$\begin{array}{l}\text { Keterampila } \\
\mathrm{n} \text { berpikir } \\
\text { luwes }\end{array}$} & $\begin{array}{l}\text { 3) Menghasilkan gagasan yang } \\
\text { bervariasi }\end{array}$ & 22 & 81,48 & Baik \\
\hline & $\begin{array}{l}\text { 4) } \begin{array}{l}\text { Dapat melihat masalah dari } \\
\text { berbagai sudut pandang yang } \\
\text { berbeda }\end{array} \\
\end{array}$ & 21 & 77,78 & Baik \\
\hline & $\begin{array}{l}\text { 5) Dapat menerapkan konsep, sifat, } \\
\text { atau aturan dalam contoh } \\
\text { pemecahan masalah }\end{array}$ & 26 & 96,30 & $\begin{array}{l}\text { Sangat } \\
\text { Baik }\end{array}$ \\
\hline \multirow{2}{*}{$\begin{array}{l}\text { Keterampila } \\
\mathrm{n} \text { berpikir } \\
\text { orisinil }\end{array}$} & $\begin{array}{l}\text { 6) Mencetuskan masalah, gagasan } \\
\text { atau hal-hal yang tidak } \\
\text { terpikirkan orang lain }\end{array}$ & 23 & 85,19 & $\begin{array}{l}\text { Sangat } \\
\text { Baik }\end{array}$ \\
\hline & $\begin{array}{l}\text { 7) Menciptakan ide-ide atau hasil } \\
\text { karya yang berbeda dan betul- } \\
\text { betul baru }\end{array}$ & 25 & 92,59 & $\begin{array}{l}\text { Sangat } \\
\text { Baik }\end{array}$ \\
\hline \multirow{2}{*}{$\begin{array}{l}\text { Keterampila } \\
\mathrm{n} \text { berpikir } \\
\text { detail } \\
\text { (elaborasi) }\end{array}$} & \begin{tabular}{|l} 
8) $\begin{array}{l}\text { Mengembangkan atau } \\
\text { memperkaya gagasan orang lain }\end{array}$ \\
\end{tabular} & 24 & 88,89 & $\begin{array}{l}\text { Sangat } \\
\text { Baik }\end{array}$ \\
\hline & $\begin{array}{l}\text { 9) Membuat laporan dengan detail } \\
\text { dan berbeda }\end{array}$ & 24 & 88,89 & $\begin{array}{l}\text { Sangat } \\
\text { Baik }\end{array}$ \\
\hline \multirow{2}{*}{$\begin{array}{l}\text { Rasa ingin } \\
\text { tahu }\end{array}$} & $\begin{array}{l}\text { 10) Keinginan untuk mencari tahu, } \\
\text { mendalami pengetahuan lebih } \\
\text { dalam }\end{array}$ & 26 & 96,30 & $\begin{array}{l}\text { Sangat } \\
\text { Baik }\end{array}$ \\
\hline & 11) Mempertanyakan segala sesuatu & 24 & 88,89 & $\begin{array}{l}\text { Sangat } \\
\text { Baik }\end{array}$ \\
\hline $\begin{array}{l}\text { Bersikap } \\
\text { merasa } \\
\text { tertantang }\end{array}$ & $\begin{array}{l}\text { 12) Melibatkan diri dalam tugas yang } \\
\text { diberikan }\end{array}$ & 26 & 96,30 & $\begin{array}{l}\text { Sangat } \\
\text { Baik }\end{array}$ \\
\hline
\end{tabular}

\section{Sumber : Pengolahan Pribadi}

Peningkatan kreativitas belajar mahasiswa pada siklus II dapat dilihat pada diagram batang di bawah ini:

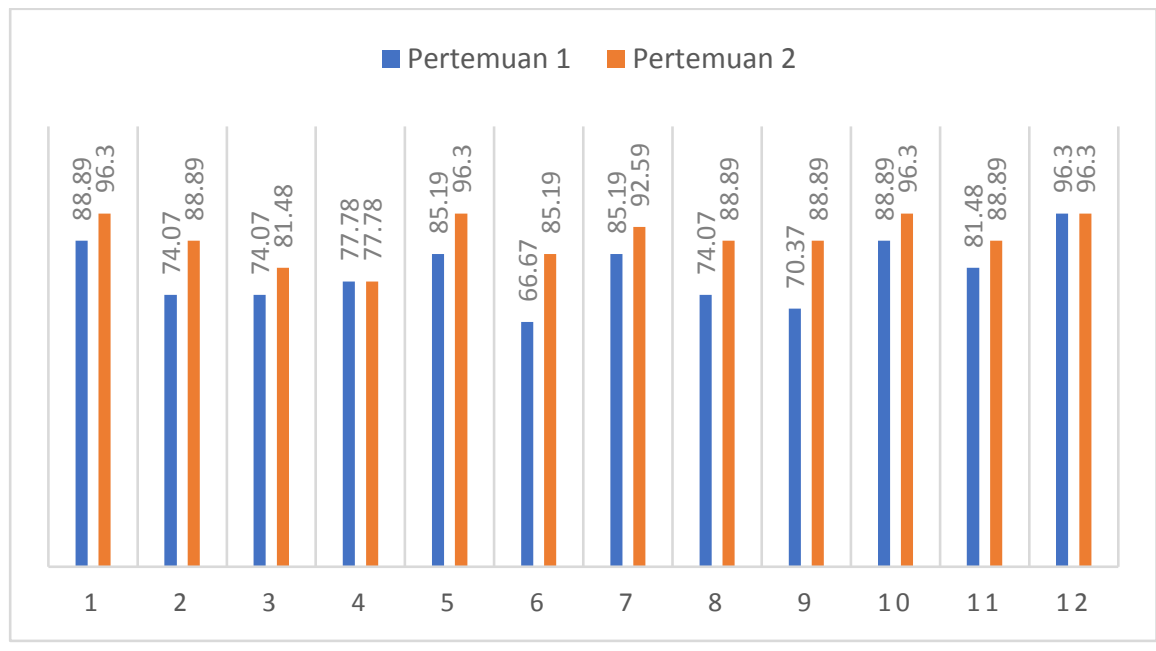


Gambar 3. Diagram Peningkatan Kreativitas Belajar Mahasiswa Siklus II

Tahap Refleksi

Setelah pelaksanaan tindakan siklus II dilaksanakan, peneliti bersama observer melakukan refleksi untuk mengevaluasi kreativitas mahasiswa yang diperoleh pada siklus II. Refleksi didasarkan pada hasil angket dan lembar observasi. Dari hasil refleksi diketahui bahwa pada siklus II penerapan model pembelajaran Brainstoming pada Mata Kuliah Pengantar Geografi telah menampakkan hasil yang baik. Berdasarkan hasil penelitian di siklus II. Berdasarkan data hasil pengamatan diketahui bahwa mahasiswa menjadi lebih kreatif selama proses perkuliahan berlangsung dan kekurangan pada siklus sebelumnya sudah mengalami perbaikan dan peningkatan sehingga mencapai sangat baik dengan perolehan persentase pada siklus II sebesar 85,03\% dengan kategori baik.

Hasil yang diperoleh sebagian besar mahasiswa menunjukkan kreativitas belajar yang lebih baik dibandingkan dengan kemampuan pada siklus I, dan dari hasil pelaksanaan perbaikan perkuliahan dan refleksi siklus II maka dapat disimpulkan bahwa pelaksanaan tindakan pembelajaran untuk meningkatkan kemampuan metakognisi dan kreativitas mahasiswa dalam Mata Kuliah Pengantar Geografi dapat diakhiri pada siklus II.

\section{KESIMPULAN}

Berdasarkan hasil penelitian dengan penerapan model pembelajaran Brainstroming dapat ditarik kesimpulan dengan menerapkan model pembelajaran Brainstroming pada Mata Kuliah Pengantar Geografi kreativitas belajar mahasiswa dapat ditingkatkan. Hasil pengamatan menunjukkan bahwa kreativitas belajar mahasiswa pada siklus I mencapai ratarata $66,20 \% \%$. kemudian meningkat pada siklus II dengan persentase rata-rata kreativitas mahasiswa sebesar $85,03 \%$.

Jadi, setalah dilakukan tindakan dengan menggunakan model pembelajaran Brainstroming pada Mata Kuliah Pengantar Geografi dapat meningkatkan kemampuan kreativitas mahasiswa dalam.

\section{DAFTAR PUSTAKA}

Ali, Mohammad. dan Mohammad Asrori. 2012. Psikologi Remaja Perkembangan Peserta Didik. Jakarta: PT. Bumi Aksara.

Agung, Iskandar. (2014). Mengembangkan Profesionalitas Guru. Bee Media Pustaka. Jakarta

Ajeyalemi, D.A. 1993. Teacher Strategies Used by Exemplary STS Teachers. What Research Says to the Science Teaching, VII. Washington D.C.: National Science Teachers Association.

Anderson, L. W., Karthwohl, D. R. (2010). A Taxonomy for Learning, Teaching, and Assessing. New York: Addison Wesley Longman

Ardian, A., \& Djatmiko, R. D. (2008). Penerapan Model Pembelajaran Brainstorming untuk Meningkatkan Kreativitas Mahasiswa pada Mata Kuliah Praktik Fabrikasi. Jurnal Pendidikan Teknologi dan Kejuruan, 17(1), 61-76.

Arikunto,S, 1993, Prosedur Penelitian Suatu Pendekatan Praktik, Rineka Cipta Jakarta

Arikunto, S. 2006. Metode Penelitian Kualitatif. Jakarta: Bumi Aksara

Arikunto, Suharsimi. 2010. Prosedur Penelitian Suatu pendekatan Praktek. Jakarta: Rineka Cipta.

Asduri, S. (2017). Efektivitas Penerapan Efektivitas Penerapan Metode Brainstorming Terhadap Pembelajaran Matematika Kelas VII SMP Negeri 4 Sungguminasa (Doctoral dissertation, Pascasarjana).

Bahar, R. (2016). Implementasi Metode Pembelajaran Brainstorming Untuk Meningkatkan Kemampuan Koneksi Matematika Hubungannya Dengan Metakognisi Siswa (Doctoral dissertation, UNPAS).

Driver, R and Leach, J. (1993). A Constructivistview of Learning : Children's Conceptions and Nature of Science. What research says to the Science Teacher. 
7.103-112. Washington : National science Teachers Association

Peraturan Pemerintah Nomor 17 Tahun 2010 tentang Pengelolaan dan Penyelenggaraan Pendidikan (Lembaran Negara Republik Indonesia Tahun 2010 Nomor 23, Tambahan Lembaran Negara Republik Indonesia Nomor 4965).

Sartono, (2013).

Tersedia:

http://soccialeducation.blogspot.com/2012/0 4/teori-dan pengembangan-kreativitasanak.html (diunduh 10 Juli 2019).

Slameto. 2003. Belajar dan Faktor-faktor yang Mempengaruhinya. Jakarta: Rineka Cipta.

Sugiyono. 2005. Memahami Penelitian Kualitatif. Bandung: CV. Alfabeta.

Suparlan; Dasim Budimansyah; dan Danny Meirawan. (2009). PAKEM : Pembelajaran Aktif,Kreatif, Efektif, dan Menyenangkan. Bandung: PT Genesindo 